\title{
Surveys on Propithecus verreauxi deckeni, a melanistic variant, and $P$. v. coronatus in north-west Madagascar
}

\author{
Deborah J. Curtis, Arsène Velo, Evelyne-Odette Raheliarisoa, Alphonse \\ Zaramody and Pie Müller
}

Propithecus verreauxi is currently divided into three or four subspecies.

Decken's sifaka, P. v. deckeni, and the crowned sifaka, P. v. coronatus, are

believed to be synonymous by some authors, while others regard them as separate

subspecies. The results of a survey on an isolated melanistic population of Decken's

sifaka, known from museum specimens collected in Ambararatabe, as well as the results of additional surveys carried out within the ranges of $\mathrm{P} . \mathrm{v}$. deckeni and $\mathrm{P}$.

v. coronatus are presented. A detailed description and photographs of the melanistic variant are provided. The data are employed to argue the case for recognition of the subspecific status of the endangered $\mathrm{P}$. v. coronatus. The consistency of sightings of $\mathrm{P}$. $\mathrm{v}$. coronatus to the east of the river Mahavavy and to the west of the river Betsiboka, and sightings of $\mathrm{P}$. $\mathrm{v}$. deckeni to the west of the Mahavavy indicate clear separation of the two subspecies in the lower reaches of the two rivers. Clarification of the status of the enigmatic museum specimens from Ambararatabe, representing a melanistic form rather than hybridization of $\mathrm{P} . \mathrm{v}$. deckeni and P. v. coronatus, lends further support to this argument.

\section{Introduction}

Propithecus verreauxi is one of three species of Propithecus, Family Indridae, found in Madagascar. Its geographical range extends from the north-west to the south-west of the country, and three or four subspecies are generally recognized (Tattersall, 1982; Figure 1). A substantial body of information is available on the northern subspecies $P$. v. coquereli as well as on the southern subspecies $P$. $v$. verreauxi (e.g. Richard, 1978; Richard et al., 1991). However, little work has been carried out on the other two subspecies, P. $v$. deckeni and P. $v$. coronatus, and some authors question the subspecific status of the latter (Tattersall, 1982, 1986,1988 ), which has led to it occasionally being grouped with $P$. $v$. deckeni (e.g. Harcourt and Thornback, 1990).

Chromatic variation is well documented in $P$. v. verreauxi and is also known to occur in (C) $1998 \mathrm{FFI}$, Oryx, 32 (2), 157-164
P.v.deckeni (Petter and Peyrieras, 1972; Tattersall, 1986). Observations of melanistic individuals in Decken's sifaka were made in the Bongolava, and museum specimens of a melanistic variant were collected by the 19291931 Archbold Expedition at Ambararatabe (Figure 1; Petter and Peyrieras, 1972; Tattersall, 1986; Thalmann and Rakotoarison, 1994).

During brief surveys carried out in the region of Lac Kinkony in 1995 a melanistic variant of $P$. $v$. deckeni was found at Analabe in the riverine forests to the west of the Mahavavy and to the east of Lac Kinkony. It appears to be geographically isolated and is probably the same population that the Archbold Expedition collected specimens from between 1929-1931 (Tattersall, 1986). A detailed description of this variant is provided here as well as the results of the survey carried out at Analabe. In addition, results are presented of all brief surveys carried out in 1994 and 1995 between the 
rivers Betsiboka and Mahavavy on P. v. coronatus and west of the Mahavavy on $P$. $v$. deckeni (Figure 1).

\section{Methods}

$P . v$. coronatus and pure white $P . v$. deckeni are clearly distinguishable to the eye. The pelage of the crowned sifaka is described as follows. The face is black, naked, or with some short whitish hairs on the muzzle. The fur of the crown, forehead, cheeks and throat is dark chocolate brown or black (Figure 2e), and there is sometimes slight white tufting around the ears. The shoulders and back are variably tinted, ranging from yellow-gold to silverbrown. The tail and hindlimbs are white. The chest is dark and lightens towards and across the abdomen. The pelage of Decken's sifaka differs in a number of ways. The face is black, the ears naked but largely hidden. The fur of many individuals is completely white (Figure 2d), while in others the back, limbs and,

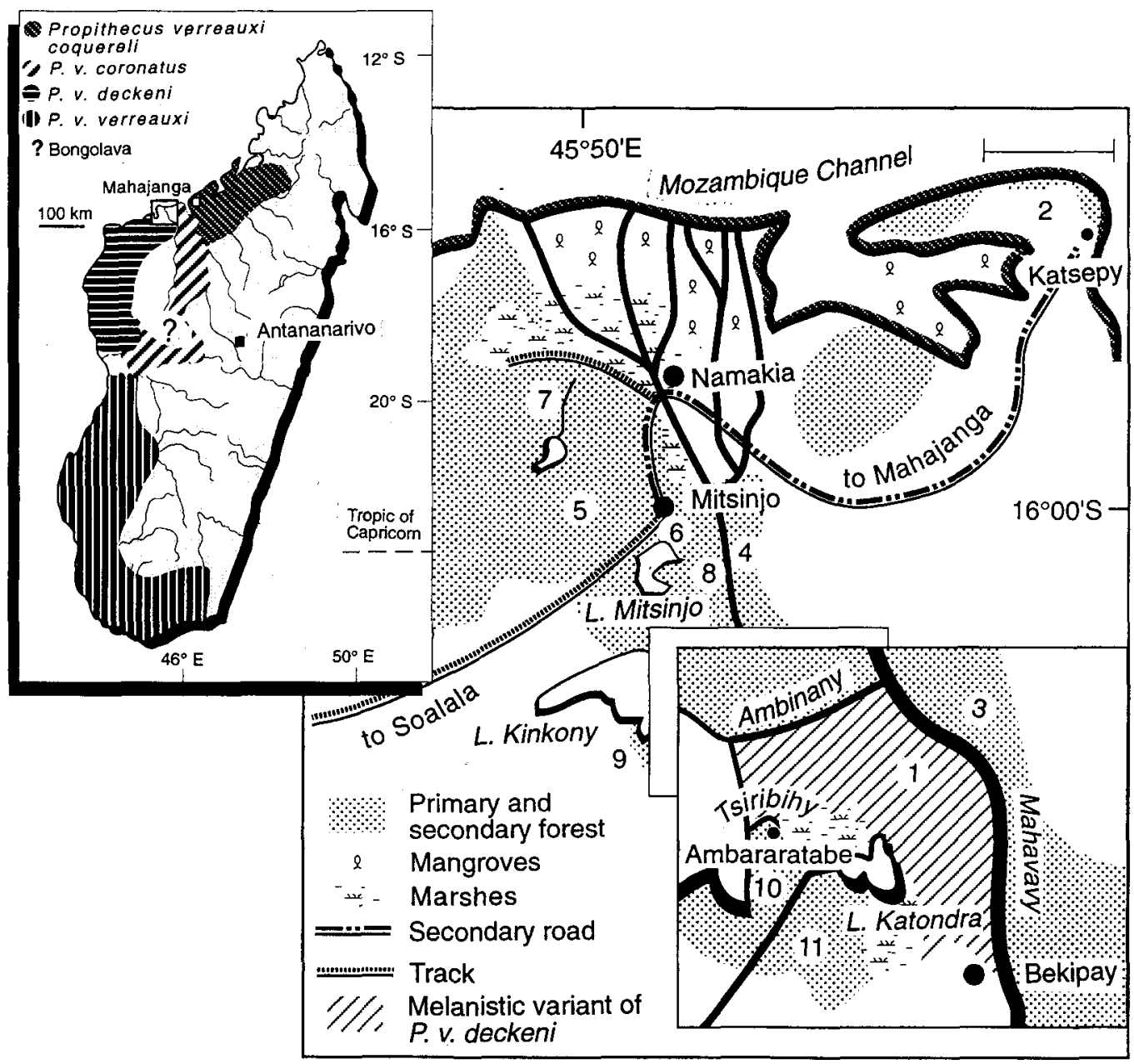

Figure 1. Distribution of Propithecus verreauxi (map) and location of areas surveyed including the proposed isolate where the melanistic population of $P . v$. deckeni is to be found (insets). Areas surveyed: 1, Analabe; 2 , Katsepy; 3, Anaborengy; 4, Anjamena; 5, Tsiombikibo South; 6, Mitsinjo; 7, Tsiombikibo North; 8, Anadabomandry; 9, Antseza; 10, Thopy West; 11, Thopy East. Adapted from: Tattersall (1982); Carte de Madagasikara 1:500 000 (Anon., 1986); Nicoll and Landgrand (1989); Thalmann and Rakotoarison (1994). 
particularly, the shoulders are touched with pale yellow-gold or silver-grey tints. The fur is short and sparse ventrally, revealing black skin (Tattersall, 1982). Based on these differences, the two subspecies were easily identified in the field.

The area surveyed at Analabe on 26 July 1995 from 08.05 to $16.10 \mathrm{~h}$ covered approximately $6 \mathrm{sq} \mathrm{km}$. The census was carried out on foot. A standard 10 minutes were spent counting individuals in each group as well as attempting to classify the individuals according to their age and sex (Eisenberg, 1981). However, if a group was resting it was sometimes possible to accomplish this in less than 10 minutes before moving on. A further $4 \mathrm{~km}$ between Analabe and the river Ambinany were surveyed from the river on 25 and 29 July and on 10 August 1995 (Figure 1; Table 1).

A number of other localities within the ranges of $P . v$. coronatus and $P . v$. deckeni were surveyed between 1994 and 1995, covering approximate areas of $1 \mathrm{sq} \mathrm{km}$ (Ihopy W), $3 \mathrm{sq} \mathrm{km}$ (Katsepy, Anaborengy, Antseza, Ihopy E) and $6 \mathrm{sq} \mathrm{km}$ (Anadabomandry) (Figure 1; Table 2).

Density estimates (number of individuals/ $\mathrm{sq} \mathrm{km}$ ) were calculated for each locality by dividing the number of animals sighted by the area surveyed. These values should be treated with caution because they are based on counts made on one day only and it was sometimes difficult to adequately assess the size of the area surveyed.

\section{Results}

\section{Description of the melanistic variant}

In the melanistic variant the entire head including the dorsal surface of the neck is dark brown or black. The dorsal coloration of the upper arms, shoulders and cranial half of the back is light brown or silvery grey. This coloration gets progressively lighter on the caudal half of the back and tail, and the caudal half of the tail is entirely white. The ventral surface of the arms and the chest are dark brown, the legs light brown or silvery grey ventrally. The dorsal surface of the forearms and legs is white (Figures $2 \mathrm{a}$ and $\mathrm{b}$ ). The coloration of $\mathrm{a}$ lighter melanistic variant seen only infrequently is white, with the exception of the chest, which is dark brown. The fur on the head varies from off-white to silvery grey (Figure 2c).

\section{Surveys and density estimates}

Groups of pure white P.v.deckeni, mixed groups containing the melanistic variant and pure white individuals, and one group consisting of melanistic individuals only (including a melanistic infant) were seen at Analabe. The variant accounted for 25 per cent and pure white $P . v$. deckeni for 75 per cent of all individuals sighted (Table 1). There was no indication of sex- or age-class dependence in coloration in this population.

All other localities to the west of the Mahavavy revealed only pure white $P$. $v$. deckeni. Surveys to the east of the river and further north at Katsepy were equally consistent in that only P.v. coronatus was found (Table 2). This indicates a clear separation of the two subspecies in the lower reaches of the Mahavavy.

Density estimates for $P$. $v$. deckeni range between 3 and 23 animals per sq $\mathrm{km}$ and are as follows: Analabe 23 animals per $\mathrm{sq} \mathrm{km}$; Anadabomandry 3 per sq km; Antseza 5 per $\mathrm{sq} \mathrm{km}$; Ihopy West 5 per sq km; Ihopy East 10 per sq $\mathrm{km}$. Estimates for $P$. $v$. coronatus were 5 per sq $\mathrm{km}$ at Katsepy and 32 per sq $\mathrm{km}$ between Anaborengy and Anjamena.

\section{Discussion}

\section{Melanization in $\mathrm{P}$. verreauxi}

Melanization in P.v. verreauxi is well documented and groups consisting entirely of melanistic individuals, as well as mixed groups have been observed (Tattersall, 1982, 1986). The situation is less clear in the case of $P . v$. deckeni and P. v. coronatus. Field sightings of P. $v$.deckeni in the Bongolava report on groups containing only pure white individuals and mixed groups of white as well 

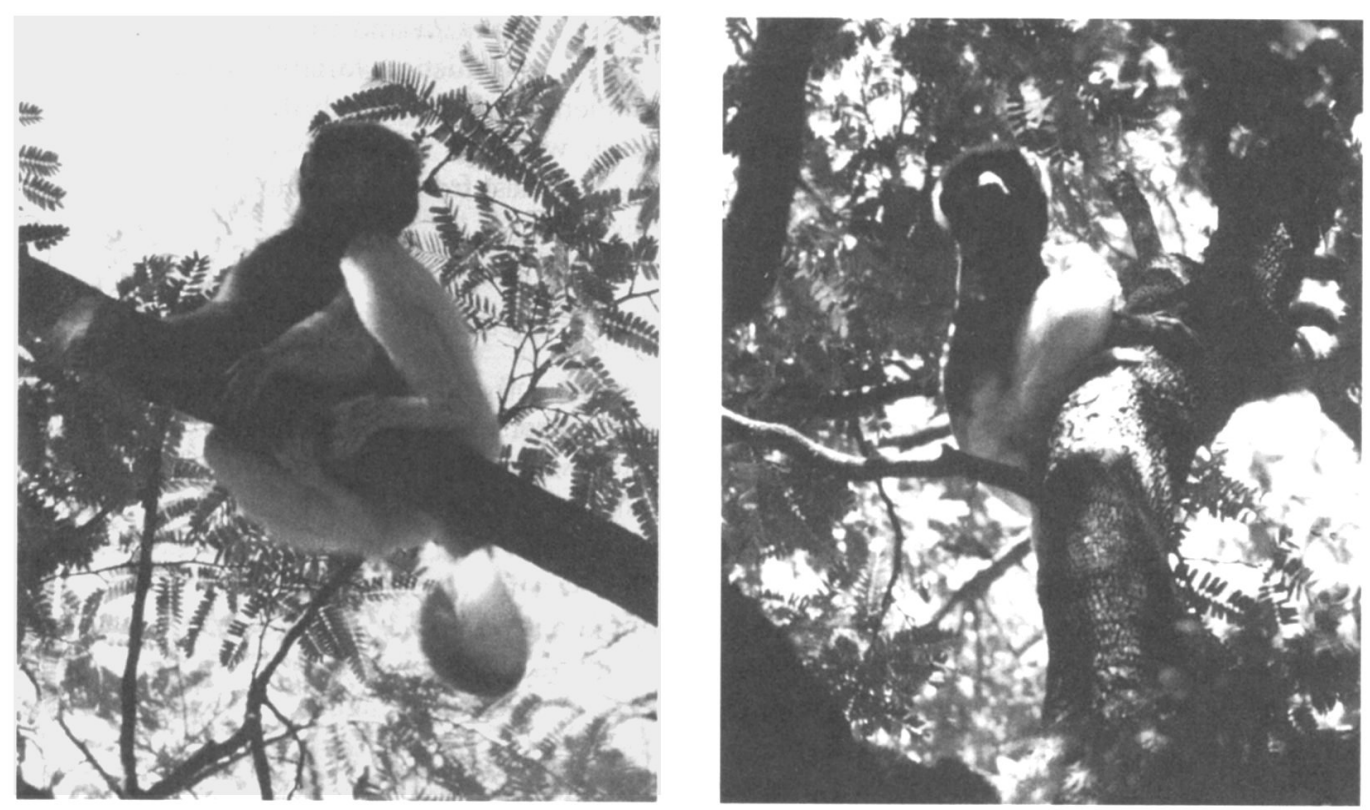

Figures $2 \mathbf{a}$ and 2b. P. v. deckeni, melanistic form (D. J. Curtis).

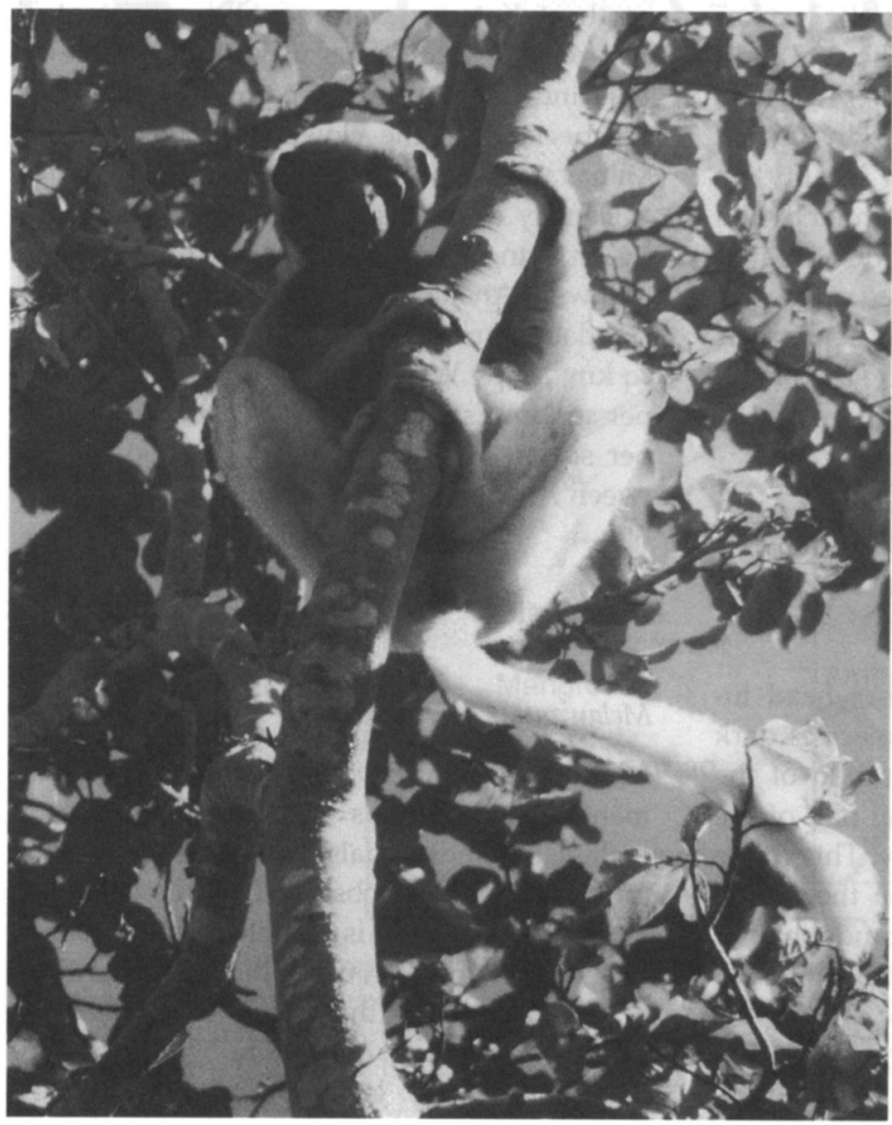

160
Figure 2c. P. v. deckeni, lighter melanistic form (D. J. Curtis).

(C) $1998 \mathrm{FFI}$, Oryx, 32 (2), 157-164 


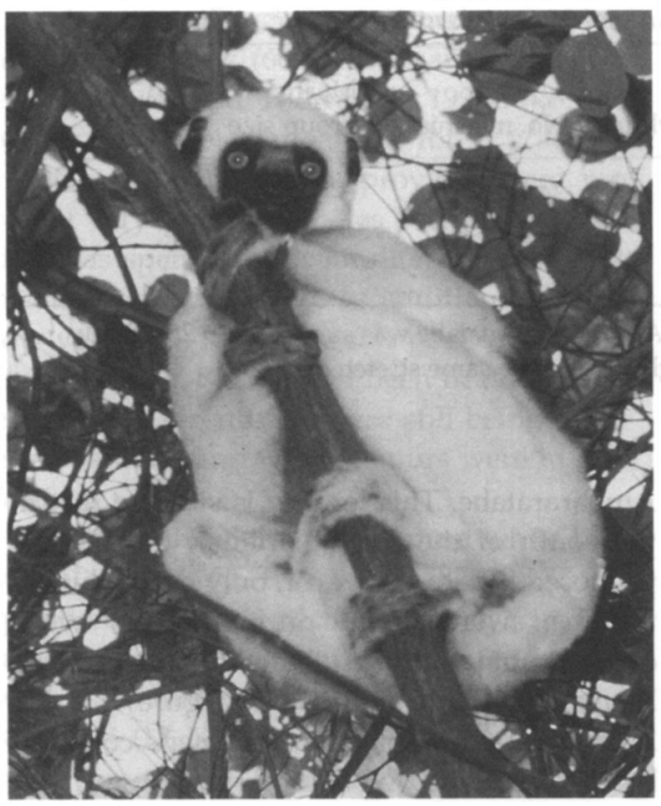

Figure 2d (above). P. $v$. deckeni, pure white form (D. J. Curtis).

Figure 2e (right). P. v. coronatus. (P. Müller).

as melanistic variants. Museum specimens from Ambararatabe are much darker than normal (Petter and Peyrieras, 1972; Tattersall, 1986). Chromatic variation has also been reported for P. v.coronatus in the Bongolava (Petter and Peyrieras, 1972), and to the south of the river Manambolo near Bekopaka, as well as at Katsepy on the Bay of Bombetoka, a pure white individual was sighted in a group of P. v. coronatus (Tattersall, 1982, 1988; Thalmann and Rakotoarison, 1994). No variation in coloration has been noted in the northernmost subspecies $P$. $v$. coquereli.

Individuals that fit the description of the chromatic variant described here were collected by the Archbold Expedition in 19291931 at Ambararatabe, just south of Analabe, and provisionally assigned to $P$. v. coronatus (Buettner-Janusch and Tattersall, 1985; Tattersall, 1986). Petter and Peyrieras (1972) described a specimen of this variant from the collection of the British Museum, also collected at Ambararatabe, but assigned it to P. $v$. deckeni. However, this variant exhibits pelage characteristics found neither in P.v.deckeni nor in $P$. $v$. coronatus and, as has been noted by

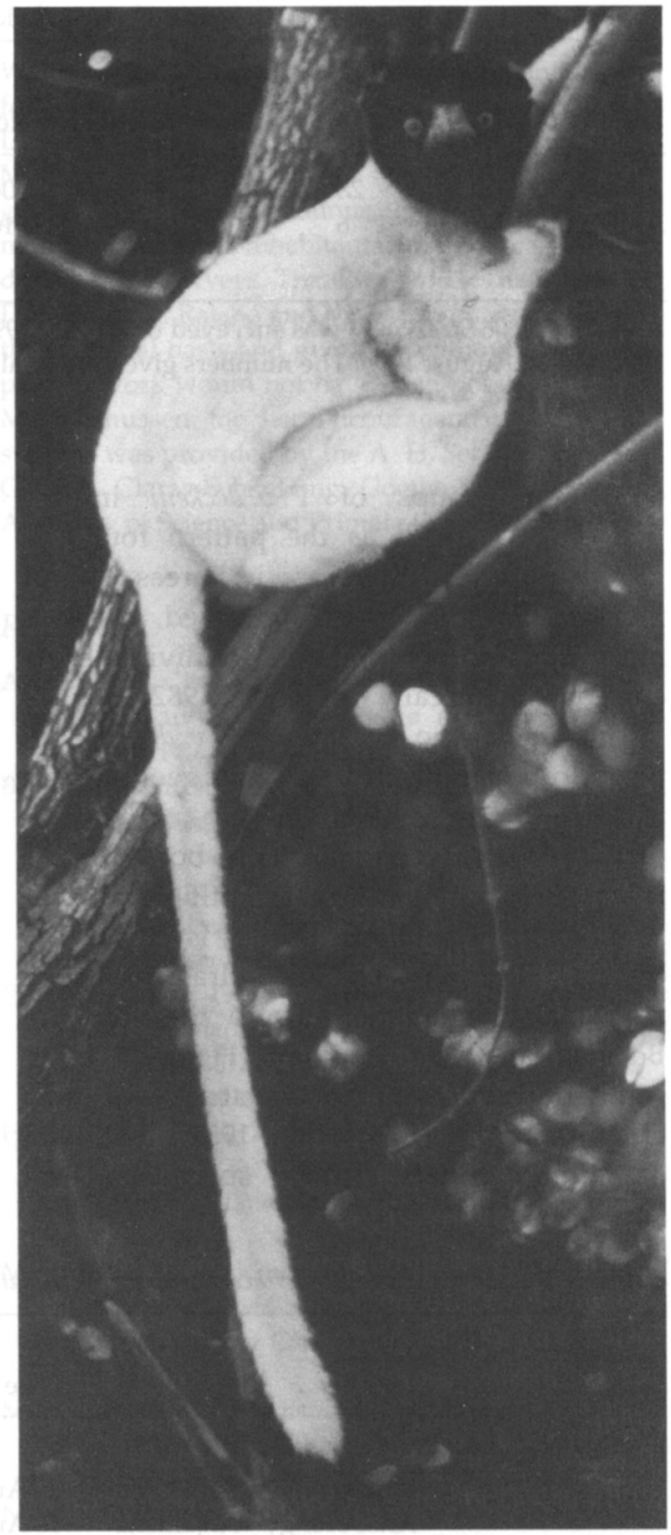

Tattersall (1986), bears no resemblance to hybrids of the two subspecies (Petter, 1969). The few intermediates sighted during this study, combined pelage features of the melanistic form and the pure white form. Groups of pure white individuals, mixed groups containing the melanistic variant and pure white individuals, and one group consisting of melanistic individuals only were sighted. This pattern resembles that reported by Petter and Peyrieras 
Table 1. Results of surveys carried out on a melanistic variant of P. v. deckeni

\begin{tabular}{llllll}
\hline & $\begin{array}{l}\text { Total no. } \\
\text { Locality }\end{array}$ & $\begin{array}{l}\text { Total no. } \\
\text { individuals }\end{array}$ & No. white & No.melanistic & $\begin{array}{l}\text { Mean } \\
\text { group size }\end{array}$ \\
\hline Analabe & 28 & 138 & 104 & 34 & 5 \\
Ambinany-Analabe & 6 & 18 & 16 & 2 & 3
\end{tabular}

Analabe (16 $\left.06^{\prime} \mathrm{S} ; 45^{\circ} 56^{\prime} \mathrm{E}\right)$ was surveyed on 26 July 1995; Ambinany-Analabe was surveyed on 25-29 July 1995 and 10 August 1995. The numbers given are total sightings on the same stretch of river.

(1972) in groups of P.v. deckeni in the Bongolava as well as the pattern found in groups of P. v. verreauxi in areas where melanization has been observed, because melanistic and non-melanistic individuals occurred sympatrically (Tattersall, 1982, 1986).

This melanistic variant of P.v. deckeni appears to be restricted to a small geographical isolate to the east of Lac Kinkony and the west of the Mahavavy. The northern border is the river Ambinany, the main effluent of Lac Kinkony. The southern border is created by the river Tsiribihy, Lac Katondra and associated marshlands, the hills to the south of Bekipay and Lac Kinkony (Figure 1). The southern border of this isolate is the least clear, because the 1929-1931 Archbold Expedition collected their specimens near
Ambararatabe. This locality is situated just to the south of the river Tsiribihy, outside the proposed isolate. However, only pure white $P$. v. deckeni were found during survey work carried out south of Ambararatabe in the Ihopy forest and at Antseza (Figure 1; Table 2). It is possible that the specimens collected by the Archbold Expedition were found just north of the Tsiribihy but this was impossible to verify because very little forest remains in the immediate vicinity of Ambararatabe.

\section{Surveys and density estimates}

Estimates provided by this study appear to be fairly low compared with density estimates for P.v. coronatus at Anjamena (173 individuals per sq km; Müller, 1997), P. v. verreauxi

Table 2. Results of surveys carried out on $P . v$. coronatus and $P . v$. deckeni

\begin{tabular}{llllll}
\hline Subspecies & Locality & Date & $\begin{array}{l}\text { No. } \\
\text { groups }\end{array}$ & $\begin{array}{l}\text { No. } \\
\text { individuals }\end{array}$ & $\begin{array}{l}\text { Mean } \\
\text { group size }\end{array}$ \\
\hline P.v. coronatus & & & & \\
& Katsepy & 25 August 1995 & 4 & 15 & 4 \\
& Anaborengy-Anjamena & 10 August 1995 & 17 & 96 & 6 \\
P. v. deckeni & & & & \\
& Tsiombikibo S & 22 May 1994 & 1 & 2 & 2 \\
& Mitsinjo & 23 May 1994 & 2 & $?$ & $?$ \\
& Tsiombikibo N & 25-26 May 1994 & 4 & $?$ & $?$ \\
& Anadabomandry & 10 September 1994 & 4 & 19 & 5 \\
& Antseza & 23-24 July 1995 & 3 & 15 & 5 \\
& Ihopy W & 15-16 August 1995 & 5 & 20 & 4 \\
\hline
\end{tabular}

Katsepy $\left(15^{\circ} 46^{\prime} \mathrm{S} ; 46^{\circ} 15^{\prime} \mathrm{E}\right)$, Anaborengy (16 $\left.05^{\circ} \mathrm{S} ; 45^{\circ} 56^{\prime} \mathrm{E}\right)$, Anjamena (16 $\left.03^{\prime} \mathrm{S} ; 45^{\circ} 55^{\prime} \mathrm{E}\right)$, Tsiombikibo South

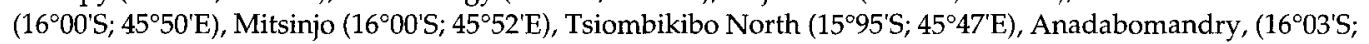
$\left.45^{\circ} 54^{\prime} \mathrm{E}\right)$, Antseza $\left(16^{\circ} 13^{\prime} \mathrm{S} ; 45^{\circ} 53^{\prime} \mathrm{E}\right)$, Ihopy West \& East $\left(16^{\circ} 15^{\prime} \mathrm{S} ; 45^{\circ} 58^{\prime}\right)$. 
(ranging from 47 to 500 individuals per sq $\mathrm{km}$ ) and $P . v$. coquereli (60 individuals per sq $\mathrm{km}$; e.g. Harcourt and Thornback, 1990). No data are available for comparison for $P$. $v$. deckeni. However, all the values provided here represent very rough estimates because only one day was spent at each locality and hence are most certainly too low. In addition, the very low values (3-10 individuals per sq $\mathrm{km}$ ) stem from areas that had either been heavily deforested fairly recently or were still being deforested rapidly, and where lemurs were hunted for food.

Based on the sighting of a pure white individual at Katsepy, Tattersall $(1982,1986,1988)$ questioned the subspecific status of $P . v$. coronatus. However, the results presented here, as well as a number of other observations at Katsepy (M. Nicoll, pers. comm.; D. Reid, pers. comm.; U. Thalmann, pers. comm.) report only sightings of individuals conforming to the P. $v$. coronatus type. Surveys carried out further inland to the east of the Mahavavy (this study; Müller, 1997), as well as surveys to the west of the river Bestiboka (near Ambato Boéni) also indicate the sole presence of $P . v$. coronatus between the rivers Mahavavy and Betsiboka (R. D. Martin, pers. comm.; Tattersall, 1982; Rabemazava, 1990). The situation in the Bongolava where the ranges of $P$. $v$. coronatus and $P$.v. deckeni meet remains enigmatic and more surveys are necessary before a better understanding can be reached (Thalmann and Rakotoarison, 1994). In view of the overall consistency of sightings of $P . v$. deckeni to the west of the Mahavavy and $P$. $v$. coronatus to the east, there does not at present appear to be any justifiable reason for disputing the subspecific status of $P$. $v$. coronatus. Given the high conservation rating of 7 assigned by Mittermeier et al. (1992), the implications for its conservation are dire if it continues to be regarded as belonging to the chromatically variable $P$. $v$. deckeni (Tattersall, 1988) and is not recognized as a subspecies in its own right: This lemur is highly threatened and is not known to be present in any protected area (Mittermeier et al., 1992; Thalmann and Rakotoarison, 1994).

\section{Acknowledgements}

We thank the Malagasy governmental organizations for research permission, in particular the staff of the Département des Eaux et Forêts in Antananarivo, Mahajanga and Mitsinjo. A special thanks to our guides, O.D. Rabetsimialona and A. Blaise, and many of the local inhabitants of the areas visited during these surveys. Thanks go to U. Thalmann, R. D. Martin, M. Rajabo and M. Zafisoan for providing the logistical basis and guidance without which the present work would not have been possible, and to M. Rasmussen for her encouragement. Financial support was provided by the A. H. Schultz Stiftung, G. \& A. Claraz-Schenkung, Goethe Stiftung, Swiss Academy of Science and Primate Conservation Inc.

\section{References}

Anon. 1986. Carte de Madagasikara 1:500 000. FTM, Institut National de Géodésie et Cartographie, Antananarivo.

Buettner-Janusch, J. and Tattersall, I. 1985. An annotated catalogue of Malagasy primates (Families Lemuridae, Indriidae, Daubentoniidae, Megaladapidae, Cheirogaleidae) in the collections of the American Museum of Natural History. American Museum Novitates, 2834, 1-45.

Eisenberg, J.F. 1981. Techniques for the Study of Primate Population Ecology. Subcommittee on Conservation of Natural Populations, National Academy Press, Washington DC.

Harcourt, C. and Thornback, J. 1990. Lemurs of Madagascar and the Comoros (The IUCN Red Data Book). IUCN, Gland, Switzerland and Cambridge, UK.

Mittermeier, R.A., Konstant, W.R., Nicoll, M.E. and Langrand, O. 1992. Lemurs of Madagascar: an Action Plan for their Conservation 1993-1999. IUCN, Gland, Switzerland.

Müller, P. 1997. Ökologie und Ernährungsstrategie des Kronensifakas (Propithecus verreauxi coronatus). Diploma thesis, University of Zürich.

Nicoll, M.E. and Langrand, O. 1989. Madagascar: Revue de la Conservation et des Aires Protégées. WWF, Gland, Switzerland.

Petter, J.-J. 1969. Speciation in Madagascan lemurs. Biological Journal of the Linnean Society, 1, 77-84.

Petter, J.-J. and Peyrieras, A. 1972. Melanization in the genus Propithecus Malagasey Lemur. Journal of Human Evolution, 1, 379-388.

Rabemazava, M. 1990. Statut et distribution du Propithèque couronné (Propithecus verreauxi coronatus) et proposition de mesures de protection. Rapport de stage de l'Ecole pour la Formation de Spécialistes de la Faune, Garona, Cameroun. 
Richard, A.F. 1978. Behavioral Variation, Case Study of a Malagasy Lemur. Bucknell University Press, Lewisburg.

Richard, A.F., Rakotomanga, P. and Schwartz, M. 1991. Demography of Propithecus verreauxi at Beza Mahfaly: sex ratio, survival and fertility, 1984-1989. American Journal of Physical Anthropology, 84, 307-322.

Tattersall, I. 1982. The Primates of Madagascar. Columbia University Press, New York.

Tattersall, I. 1986. Notes on the distribution and taxonomic status of some subspecies of Propithecus in Madagascar. Folia Primatologica, 46, 51-63.

Tattersall, I. 1988. Distribution survey of the Malagasy lemurs: request for information and initial report. Primate Conservation, 9, 116-117.

Thalmann, U. and Rakotoarison, N. 1994. Distribution of lemurs in central western Madagascar, with a regional distribution hypothesis. Folia Primatologica, 63, 156-161.

Deborah J. Curtis, Anthropological Institute, University Zürich-Irchel, Winterthurerstr. 190, 8057
Zürich, Switzerland. Tel: +41 163554 28; Fax: +41 1 63568 04; E-mail: djc@aim.unizh.ch

Arsène Velo, Département des Sciences de la Terre, Université de Mahajanga, BP 652, Mahajanga 401, Madagascar.

Evelyne-Odette Raheliarisoa, Département des Sciences de la Terre, Université de Mahajanga, BP 652, Mahajanga 401, Madagascar.

Alphonse Zaramody, Département des Sciences de la Terre, Université de Mahajanga, BP 652, Mahajanga 401, Madagascar.

Pie Müller, Anthropological Institute, University Zürich-Irchel, Winterthurerstr. 190, 8057 Zürich, Switzerland.

Received 14 July 1997

Accepted 2 December 1997 